Article

\title{
Crystal Structure of the Disordered Non-Centrosymmetric Compound $\mathrm{Fe}_{0.43} \mathrm{Mo}_{2.56} \mathrm{SbO}_{9.5}$
}

\author{
Sk Imran Ali ${ }^{1,2, *}$, Sven Lidin ${ }^{3}$ and Mats Johnsson ${ }^{1, *}$ \\ 1 Department of Materials and Environmental Chemistry, Stockholm University, SE-106 91 Stockholm, Sweden \\ 2 Department of Chemistry, University of Kalyani, Kalyani, Nadia, West Bengal-741235, India \\ 3 Division of Polymer and Materials Chemistry, CAS, Lund University, 22241 Lund, Sweden; \\ sven.lidin@chem.lu.se \\ * Correspondence: skimranchem18@klyuniv.ac.in (S.I.A.); mats.johnsson@mmk.su.se (M.J.); \\ Tel.: +91-973-228-9832 (S.I.A.)
}

Received: 11 December 2018; Accepted: 10 January 2019; Published: 15 January 2019

\begin{abstract}
Single crystals of $\mathrm{Fe}_{0.43} \mathrm{Mo}_{2.56} \mathrm{SbO}_{9.5}$ were obtained by hydrothermal techniques at $230{ }^{\circ} \mathrm{C}$. The crystal structure was determined from single crystal X-ray diffraction data. The compound crystallizes in the non-centrosymmetric space group Pc with unit cell parameters $a=4.0003(2) \AA$, $b=7.3355(3) \AA, c=12.6985(6) \AA, \beta=90^{\circ}$. The crystal structure comprises five crystallographically independent $\mathrm{M}$ atoms and one $\mathrm{Sb}^{3+}$ atom, $\mathrm{M}$ atoms are of two kinds of partially occupied sites $\mathrm{Mo}^{6+}$ and $\mathrm{Fe}^{3+}$. The building blocks consist of $\left[\mathrm{SbO}_{3} \mathrm{O}_{0.5} \mathrm{O}_{0.5} \mathrm{E}\right]$ octahedra $(\mathrm{E}=$ lone electron pair) and $\left[(\mathrm{Mo} / \mathrm{Fe}) \mathrm{O}_{6}\right]$ octahedra. The $M=(\mathrm{Mo}, \mathrm{Fe})$ and $\mathrm{O}$ atoms are arranged in a distorted hexagonal 2D-net, not the $\mathrm{Sb}$ atoms. The distortion of the net and consequently the symmetry reduction results mainly from the location of the $\mathrm{Sb}$ atoms. Disorder manifests itself as a splitting of the metal sites and as a consequent shortening of the Mo-Fe distances. Six $(\mathrm{Mo} / \mathrm{Fe}) \mathrm{O}_{6}$ octahedra are connected to form a pseudohexagonal channel. The $\mathrm{Sb}^{3+}$ atom is displaced from the pseudo-six-fold axis.
\end{abstract}

Keywords: hydrothermal synthesis; non-centrosymmetric (NCS) materials; X-ray diffraction; disordered structure

\section{Introduction}

The search for crystallographically non-centrosymmetric (NCS) materials is of current interest and of great importance due to the fact that such compounds may show interesting physical properties e.g., non-linear second harmonic generation, ferroelectricity etc. [1-8]. Involving cations having stereochemically active lone pairs e.g., $\mathrm{Se}^{4+}, \mathrm{Te}^{4+}, \mathrm{Sb}^{3+}, \mathrm{As}^{3+}$ and also $\mathrm{d}^{10}$ transition metal cations that are susceptible to second order Jahn-Teller distortion in the search for new compounds enhance the possibilities to form NCS materials $[9,10]$.

A large variety of ternary oxides in the $\mathrm{M}-\mathrm{Sb}-\mathrm{O}$ system $\left(\mathrm{M}=\mathrm{Mn}^{2+}, \mathrm{Fe}^{2+}, \mathrm{Co}^{2+}, \mathrm{Ni}^{2+}, \mathrm{Zn}^{2+}\right.$, $\mathrm{Mg}^{2+}$ ) have previously been described in the literature [11-15]. The oxidation state of the Sbcations plays an important role when forming different kinds of crystal structures. $\mathrm{MSb}_{2} \mathrm{O}_{4}(\mathrm{M}=\mathrm{Co}, \mathrm{Ni}$, $\mathrm{Fe}, \mathrm{Mn}$ ) crystallizes in tetragonal symmetry with space group $\mathrm{P} 4_{2} / m b c$ and forms schafarzikite type of crystal structures [11,14-16]. The crystal structure of $\mathrm{MSb}_{2} \mathrm{O}_{4}$ consists of rutile-type chains of edge-sharing $\mathrm{MO}_{6}$ octahedra which are linked together by trigonal pyramidal $\mathrm{Sb}^{3+}$ cations. The $\mathrm{Sb}^{5+}$ cations have octahedral coordination and the example compounds crystallize with the trirutile crystal structure $\mathrm{FeSbO}_{4}, \mathrm{Fe}_{2} \mathrm{Sb}_{2} \mathrm{O}_{6}, \mathrm{CoSb}_{2} \mathrm{O}_{6}$, the pyrochlore-type $\mathrm{Co}_{2} \mathrm{Sb}_{2} \mathrm{O}_{7}$ or the spinel-type compound $\mathrm{Co}_{2.5} \mathrm{Sb}_{0.5} \mathrm{O}_{4}[12,17-19]$.

There are comparatively few quaternary compounds that have been investigated so far compared to the number of ternary compounds, especially in the $\mathrm{M}-\mathrm{Co}-\mathrm{Sb}-\mathrm{O}(\mathrm{M}=\mathrm{Mo}, \mathrm{Ag}, \mathrm{Na}, \mathrm{Sr}, \mathrm{Ba})$ 
system [13,20-22]. Some of these compounds exhibit interesting magnetic properties showing e.g., spin-glass transitions at low temperatures. Examples include the layered $\mathrm{Ag}_{3} \mathrm{Co}_{2} \mathrm{SbO}_{6}$ and $\mathrm{Sr}_{2} \mathrm{CoSbO}_{6}$ and $\mathrm{Sr}_{2} \mathrm{CoSbO}_{5.63}$ (semiconductors) $\mathrm{Na}_{3} \mathrm{Co}_{2} \mathrm{SbO}_{6}$ phases [13], the distorted $\mathrm{Sr}_{3} \mathrm{CoSb}_{2} \mathrm{O}_{9}$ (insulator pervoskites [20] or the $\mathrm{Ba}_{3} \mathrm{CoSb}_{2} \mathrm{O}_{9}$ and $\mathrm{Ba}_{2} \mathrm{Co}_{1.4} \mathrm{Sb}_{0.6} \mathrm{O}_{6-y}$ phases [22]. However, there is only one such phase found in the [M-Fe-Sb-O] system; e.g., $\mathrm{FeSb}_{2-\mathrm{x}} \mathrm{Pb}_{\mathrm{x}} \mathrm{O}_{4}(\mathrm{x}=0.2-0.7)$ [23]. The replacement of $\mathrm{Sb}^{3+}$ by $\mathrm{Pb}^{2+}$ induces oxidation of $\mathrm{Fe}^{2+}$ to $\mathrm{Fe}^{3+}$. The substitution by $\mathrm{Pb}^{2+}$ leads to C-type antiferromagnetic orbital crystal structure compared to A-type antiferromagnetic orbital crystal structure for $\mathrm{FeSb}_{2} \mathrm{O}_{4}$. An example of disordered crystal structure in the $[\mathrm{Fe}-\mathrm{Mo}-\mathrm{O}]$ phase is observed e.g., $\mathrm{Fe}_{2}\left(\mathrm{MoO}_{4}\right)_{3}$. The disorder is mainly due to the Mo atom [24,25].

Compounds in the [M-Sb-O] and [M-Fe-Sb-O] systems have mainly been synthesized by solid state reactions that involve heating the constituents in a silica ampoule. The temperature varies from $500^{\circ} \mathrm{C}$ to $1600^{\circ} \mathrm{C}$ for different systems. In the present study we instead utilize a hydrothermal synthesis technique to grow single crystals of a new quaternary phase with the composition $\mathrm{Fe}_{0.43} \mathrm{Mo}_{2.56} \mathrm{SbO}_{9.5}$. The crystals show diffuse scattering in addition to the Bragg reflections. After careful examination of many crystals by single crystal X-ray diffraction we concluded that the diffuse scattering, hence disorder, is intrinsic for this compound. The evidence is even more pronounced from the fact of lowering to non-centrosymmetric monoclinic symmetry with six-fold twinning instead of the higher hexagonal symmetry. Unfortunately it was not possible to synthesize phase-pure material for further characterization of the physical properties.

\section{Materials and Methods}

A mixture of $\mathrm{FeF}_{2}: \mathrm{MoO}_{3}: \mathrm{Sb}_{2} \mathrm{O}_{3}=1: 5: 2$ in $2 \mathrm{~mL}$ deionized water plus a few droplets of $\mathrm{HF}$ were sealed in an $18 \mathrm{~mL}$ teflon lined steel autoclave and heated to $230^{\circ} \mathrm{C}$ at a rate of $1.6^{\circ} \mathrm{C} / \mathrm{min}$. The plateau temperature was maintained for four days and thereafter the temperature was lowered to $30^{\circ} \mathrm{C}$ with a rate $1.6^{\circ} \mathrm{C} / \mathrm{min}$. The following starting chemicals were used: $\mathrm{Sb}_{2} \mathrm{O}_{3}(99.97 \%$, Sigma-Aldrich, St. Louis, $\mathrm{MO}, \mathrm{USA}), \mathrm{FeF}_{2}\left(99.8 \%\right.$, Sigma-Aldrich), and $\mathrm{MoO}_{3}$ (99.5\%, Sigma-Aldrich). The hydrothermal synthesis yielded green single crystals of $\mathrm{Fe}_{0.43} \mathrm{Mo}_{2.56} \mathrm{SbO}_{9.5}$ that were washed using water and ethanol followed by drying at room temperature. An unidentified $[\mathrm{Sb}-\mathrm{Mo}-\mathrm{O}]$ phase was also found from the EDS analysis.

Single crystal X-ray diffraction data were collected using a Bruker D8 Venture diffractometer equipped with a PHOTON 100 detector. Data integration, including correction for oblique incidence, was performed with the software CrysAlis RED [26]. Absorption correction was applied with the computer program SADABS [27]. The crystal structure was solved using the program Superflip [28] and refined by using the program JANA2006 [29]. Fe, Mo, and Sb atoms were refined with anisotropic temperature parameters and oxygens were refined isotropically; the crystal refinement data is summarized in Table 1.

Chemical compositions were obtained by EDS using a Hitachi M3000 tabletop scanning electron microscope and a JEOL JSB-7000F. The content of heavy elements was found to be 10.6 at $\% \mathrm{Fe}, 61.3 \mathrm{at} \%$ $\mathrm{Mo}$, and $28.1 \mathrm{at} \% \mathrm{Sb}$, see Supplementary Materials. The expected values are $10 \mathrm{at} \% \mathrm{Fe}, 50 \mathrm{at} \% \mathrm{Mo}$ and $40 \mathrm{at} \% \mathrm{Sb}$. An unidentified [Sb-Mo-O] phase was also found as byproduct with the composition $66 \mathrm{at} \%$ $\mathrm{Sb}$ and $33 \mathrm{at} \%$ Mo respectively. 
Table 1. Crystallographic data for $\mathrm{Fe}_{0.43} \mathrm{Mo}_{2.56} \mathrm{SbO}_{9.5}$.

\begin{tabular}{|c|c|}
\hline & $\mathrm{Fe}_{0.43} \mathrm{Mo}_{2.56} \mathrm{SbO}_{9.5}$ \\
\hline formula weight/g mol${ }^{-1}$ & 543.77 \\
\hline temperature/K & 293 \\
\hline crystal system & Monoclinic \\
\hline space group & $P_{c}($ no. 7$)$ \\
\hline $\mathrm{a} / \AA$ & $4.0003(2)$ \\
\hline $\mathrm{b} / \AA$ & $7.3355(3)$ \\
\hline $\mathrm{C} / \AA$ & $12.6985(6)$ \\
\hline$\beta /{ }^{\circ}$ & 90.0 \\
\hline $\mathrm{V} / \AA^{3}$ & 372.6 \\
\hline$\rho / g . \mathrm{cm}^{-3}$ & 4.846 \\
\hline $\mathrm{Z}$ & 2 \\
\hline crystal size $/ \mathrm{mm}^{3}$ & $0.45 \times 0.15 \times 0.10$ \\
\hline radiation type & Mo- $\mathrm{K} \alpha$ \\
\hline \multirow[t]{2}{*}{ wavelength/A } & 0.71069 \\
\hline & $-8 \leq \mathrm{h} \leq 8$ \\
\hline \multirow[t]{2}{*}{ indices range } & $-15 \leq \mathrm{k} \leq 15$ \\
\hline & $-26 \leq 1 \leq 26$ \\
\hline \multicolumn{2}{|l|}{ No. of reflections } \\
\hline Measured/unique & $18,904 / 13,739$ \\
\hline observed [I > $3 \sigma(\mathrm{I})]$ & 9883 \\
\hline $\mathrm{R}_{\text {int }}$ & 0.044 \\
\hline$(\sin \theta / \lambda)_{\max } / \AA^{-1}$ & 1.03 \\
\hline \multicolumn{2}{|l|}{$\mathrm{R}_{\mathrm{F}} / \mathrm{wR} R_{\mathrm{F}}[\mathrm{F}>3 \sigma(\mathrm{F})]>$} \\
\hline All reflections (\%) & $6.30 / 7.29$ \\
\hline goodness of fit (all) & 1.59 \\
\hline
\end{tabular}

\section{Results}

\section{Crystal Structure}

The new compound $\mathrm{Fe}_{0.43} \mathrm{Mo}_{2.56} \mathrm{SbO}_{9.5}$ crystallizes in the monoclinic non-centrosymmetric space group Pc with unit cell parameters $a=4.0003(2) \AA, b=7.3355(3) \AA, c=12.6985(6) \AA, \beta=90^{\circ}$. The refined $\beta$ is 90.005 (3) which is within three times standard uncertainty. This is why we fixed the $\beta$ to $90^{\circ}$, which showed convergence and good fit to data using space group Pc (monoclinic b-axis) compared to the possible space group in the higher symmetry of the orthorhombic cell. All crystallographic parameters from the refinement are summarized in Table 1. The structural units of $\mathrm{Fe}_{0.43} \mathrm{Mo}_{2.56} \mathrm{SbO}_{9.5}$ with isotropic atomic displacement parameters and occupancies are summarized in the Supplementary Materials. Six fold twinning by fixing the volumes to one sixth was applied during the refinement. The twinning matrices are implied as follows: $(100,0-1 / 2-3 / 2,01 / 2-1 / 2) ;(100,0-1 / 23 / 2,0-1 / 2-1 / 2)$; $(-100,010,001) ;(-100,0-1 / 2-3 / 2,01 / 2-1 / 2) ;(-100,0-1 / 23 / 2,0-1 / 2-1 / 2)$. The unit cell contains one crystallographic independent $\mathrm{Sb}^{3+}$ atom and five sites by partially occupied $\mathrm{Mo}^{6+}$ and $\mathrm{Fe}^{3+}$ atoms. $\mathrm{Mo} / \mathrm{Fe}$ sites are named either by a number or a number plus a letter. These five sites are Mo1/Fe1, $\mathrm{Mo1a} / \mathrm{Fe} 1 \mathrm{a}, \mathrm{Mo} 2 / \mathrm{Fe} 2, \mathrm{Mo} 2 \mathrm{a} / \mathrm{Fe} 2 \mathrm{a}$, and Mo3/Fe3. To make the description of the crystal structure simpler we introduced $\left[\mathrm{Mo}^{*} / \mathrm{Fe}^{*}\right]$ to denote all $[\mathrm{Mo} / \mathrm{Fe}]$ sites, $\left[\mathrm{Mo1}^{*} / \mathrm{Fe}^{*}\right]$ to denote the $[\mathrm{Mo} 1 / \mathrm{Fe} 1, \mathrm{Mo} 1 \mathrm{a} / \mathrm{Fe} 1 \mathrm{a}]$ sites and $\left[\mathrm{Mo} 2^{*} / \mathrm{Fe} 2^{*}\right]$ to denote the $[\mathrm{Mo} 2 / \mathrm{Fe} 2, \mathrm{Mo} 2 \mathrm{a} / \mathrm{Fe} 2 \mathrm{a}]$ sites. The Mo1/Fe1 and Mo1a/Fe1a sites are present at a very short distance $0.71 \AA$ and are actually split positions. Disorder manifests itself as a splitting of the metal sites and as a consequent shortening of the Fe-Mo distance. A similar trend has been found for the splitting of the Mo2/Fe2 and Mo2a/Fe2a sites. However, there is no split of the $\mathrm{Mo} / \mathrm{Fe} 3$ atom. Strong evidence for disorder is observed from the diffuse scattering found from the reconstructed image of the (hk2) layers, see Figure 1. The occupancy of Mo1 (0.72) is significantly higher than the occupancy of Fe1 (0.12), Mo1a (0.13), and Fe1a (0.02), however the overall occupancy is close to 1. Similarly, the occupancy of Mo2 (0.62) is significantly higher than for Fe2 (0.11), Mo2a (0.21) and Fe2a 
(0.04) and the overall occupancy is also close to 1 . Mo3 (0.86) also has a higher occupancy than Fe3 (0.14) and together the occupancy is 1 , see Table 2 . There are ten crystallographically independent oxygen atoms that have been refined isotropically and the $\mathrm{O}(10)$ atom is half occupied in a disordered manner.

The $\mathrm{Sb}$ atom is coordinated with five oxygen atoms to complete the distorted square pyramid $\left[\mathrm{SbO}_{4}\right]$. The $\left[\mathrm{SbO}_{4}\right]$ units connected to each other by - Sb-O (10) - Sb-O (10) bridges to form a $\left[\mathrm{Sb}_{2} \mathrm{O}_{7}\right]_{\mathrm{n}}$ chain, see Figure 2a. The lone electron pair (E) sides opposite to the axial site of the pyramids to complete the distorted $\left[\mathrm{SbO}_{3} \mathrm{O}_{0.5} \mathrm{O}_{0.5} \mathrm{E}\right]$ octahedras. The Sb-O distances vary from $1.95(2) \AA$ to 2.443(7) $\AA$, see Table 3. The Sb-O distances are comparable with the distances found in cubic $\mathrm{Sb}_{2} \mathrm{O}_{3}$ and monoclinic $\mathrm{Sb}_{3} \mathrm{O}_{4} \mathrm{~F}[30,31]$. Bond distances up to $2.76 \AA$ for $\mathrm{Sb}-\mathrm{O}$ are to be considered to belong to the primary coordination sphere according to the operative definition by Brown [32].

Table 2. Occupancy factor of the partially occupied atoms in $\mathrm{Fe}_{0.43} \mathrm{Mo}_{2.56} \mathrm{SbO}_{9}$.

\begin{tabular}{cc}
\hline Atom & Occ \\
\hline Mo1 & 0.72 \\
Fe1 & 0.12 \\
Mo1a & 0.13 \\
Fe1a & 0.02 \\
Mo2 & 0.64 \\
Fe2 & 0.11 \\
\hline Mo2a & 0.21 \\
Fe2a & 0.04 \\
Mo3 & 0.86 \\
Fe3 & 0.14 \\
\hline
\end{tabular}

Both Mo1/Fe1 and Mo1a/Fe1a sites form distorted octahedral units of $\left[(\mathrm{Mo} 1 / \mathrm{Fe} 1) \mathrm{O}_{6}\right]$ and $\left[(\mathrm{Mola} / \mathrm{Fe} 1 \mathrm{a}) \mathrm{O}_{6}\right]$ respectively. The equatorial Mo/Fe-O distances are in the range 1.904(8)-2.014(11) A. The axial Mo/Fe-O distances are 1.620(7)-2.391(7) $\AA$. The short axial Mo/Fe-O distance is explained by the disorder present at the Mo1/Fe1, Mo1a/Fe1a sites. The $\left[\left(\mathrm{Mo}^{*} / \mathrm{Fe} 1^{*}\right) \mathrm{O}_{6}\right]$ octahedra are connected to each other by oxygen bridges to form a chain with the composition $\left[\left(\mathrm{Mo}^{*} / \mathrm{Fe} 1^{*}\right) \mathrm{O}_{5}\right]_{n}$. Similarly, both Mo2/Fe2 and Mo2a/Fe2a sites forms distorted [(Mo2/Fe2) $\left.\mathrm{O}_{6}\right]$ and $\left[(\mathrm{Mo} 2 \mathrm{a} / \mathrm{Fe} 2 \mathrm{a}) \mathrm{O}_{6}\right]$ octahedral and a similar chain; $\left[\left(\mathrm{Mo}^{*} / \mathrm{Fe}^{*}\right) \mathrm{O}_{5}\right]_{\mathrm{n}}$. The equatorial $\mathrm{Mo} / \mathrm{Fe}-\mathrm{O}$ distances are in the range $1.809(7) \AA$ to $2.066(9) \AA$ and the plane is shown in Figure $2 \mathrm{~b}$. The axial Mo/Fe-O distances are 1.675(6) $\AA$ and 2.329(6) $\AA$ respectively, see (Table 3). Mo3/Fe3 sites form distorted octahedra units of $\left[(\mathrm{Mo3} / \mathrm{Fe} 3) \mathrm{O}_{6}\right]$. The equatorial Mo3/Fe3-O distances are in the range 1.838(7)-2.023(8) and the axial Mo3/Fe3-O distances are in the range $1.739(5)-2.273(5) \AA$. The $\left[(\mathrm{Mo} / \mathrm{Fe} 3) \mathrm{O}_{6}\right]$ units are connected to each other by $(\mathrm{Mo} / \mathrm{Fe})-\mathrm{O}-(\mathrm{Mo} / \mathrm{Fe})$ bridges to form a $\left[(\mathrm{Mo} 3 / \mathrm{Fe} 3) \mathrm{O}_{5}\right]_{\mathrm{n}}$ chain along [1-1 $0]$, see Figure $2 \mathrm{a}$. The $\left[\left(\mathrm{Mo}^{*} / \mathrm{Fe}^{*}\right) \mathrm{O}_{5}\right]_{\mathrm{n}}$ and $\left[\left(\mathrm{Mo} 2^{*} / \mathrm{Fe}^{*}\right) \mathrm{O}_{5}\right]_{\mathrm{n}}$ chains connect to each other forming $\left[\left(\mathrm{Mo}^{*} / \mathrm{Fe}^{*}\right)\left(\mathrm{Mo}^{*} / \mathrm{Fe}^{*}\right) \mathrm{O}_{8}\right]_{n}$ layers, see Figure $3 b, c$. The $\left[(\mathrm{Mo} 3 / \mathrm{Fe} 3) \mathrm{O}_{5}\right]_{n}$ and $\left[\mathrm{SbO}_{3.5}\right]_{n}$ chains connect via edge sharing to form $\left[(\mathrm{Mo} 3 / \mathrm{Fe} 3) \mathrm{SbO}_{6.5}\right]_{\mathrm{n}}$ chains, see Figure 3a. The $\left[\left(\mathrm{Mo}^{*} / \mathrm{Fe} 1^{*}\right)\left(\mathrm{Mo}^{*} / \mathrm{Fe} 2^{*}\right) \mathrm{O}_{8}\right]_{\mathrm{n}}$ layers and the $\left[(\mathrm{Mo} 3 / \mathrm{Fe} 3) \mathrm{SbO}_{6.5}\right]_{\mathrm{n}}$ chains connect to each other by five different types of bridges, which are [(Mo1*/Fe1*)-O7-Sb1], [(Mo2*/Fe2*)-O7-Sb1], [(Mo2*/Fe2*)-O9-Sb1], [(Mo2*/Fe2*)-O9-(Mo3/Fe3)], [(Mo1*/Fe1*)-O8-(Mo3/Fe3)]. 


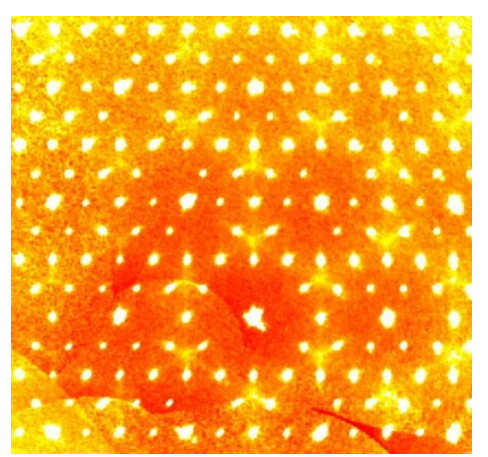

Figure 1. Reconstructed image of (hk2) layers of $\mathrm{Fe}_{0.43} \mathrm{Mo}_{2.56} \mathrm{SbO}_{9.5}$ crystal.

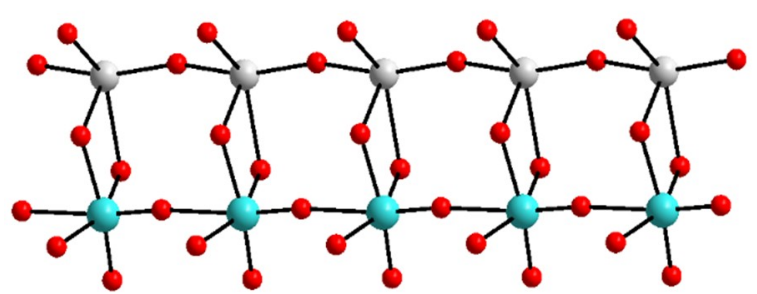

(a)

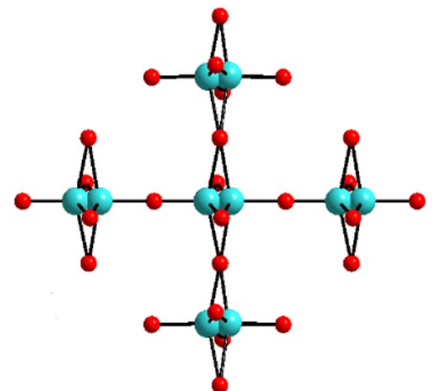

(b)

Figure 2. (a) The $\left[\mathrm{SbO}_{3.5}\right]_{\mathrm{n}}$ chains and the $\left[(\mathrm{Mo} 3 / \mathrm{Fe} 3) \mathrm{O}_{5}\right]_{\mathrm{n}}$ chains form together $\left[(\mathrm{Mo} 3 / \mathrm{Fe} 3) \mathrm{SbO}_{6.5}\right]_{\mathrm{n}}$ chains, (b) $\left[\left(\mathrm{Mo}^{*} / \mathrm{Fe}^{*}\right) \mathrm{O}_{5}\right]_{\mathrm{n}}$ and $\left[\left(\mathrm{Mo}^{*} / \mathrm{Fe}^{*}\right) \mathrm{O}_{5}\right]_{\mathrm{n}}$ chains form layers with the composition $\left[\left(\mathrm{Mo}^{*} / \mathrm{Fe} 1^{*}\right)\left(\mathrm{Mo}^{*} / \mathrm{Fe}^{*}\right) \mathrm{O}_{8}\right.$.

Table 3. Interatomic distances/ $\mathrm{A}$ in $\mathrm{Fe}_{0.43} \mathrm{Mo}_{2.56} \mathrm{SbO}_{9.5}$.

\begin{tabular}{cc}
\hline Atoms & Atom-Oxygen (O) Distances \\
\hline $\mathrm{Sb} 1$ & $1 \times 2.146(11) ; 1 \times 2.063(7) ; 1 \times 2.09(2) ; 1 \times 1.95(2) ; 1 \times 2.443(7)$ \\
$\mathrm{Mo} 1 / \mathrm{Fe} 1$ & $1 \times 2.326(6) ; 1 \times 1.680(6) ; 1 \times 1.904(8) ; 1 \times 1.927(6) ; 1 \times 2.010(7) ; 1 \times 1.942(9)$ \\
$\mathrm{Mo} 1 \mathrm{a} / \mathrm{Fe} 1 \mathrm{a}$ & $1 \times 1.620(7) ; 1 \times 2.391(7) ; 1 \times 1.946(11) ; 1 \times 1.912(9) ; 1 \times 2.014(11) ; 1 \times 1.941(11)$ \\
$\mathrm{Mo} 2 / \mathrm{Fe} 2$ & $1 \times 1.720(6) ; 1 \times 2.286(6) ; 1 \times 1.930(8) ; 1 \times 1.859(6) ; 1 \times 2.012(7) ; 1 \times 2.020(8)$ \\
$\mathrm{Mo} 2 \mathrm{a} / \mathrm{Fe} 2 \mathrm{a}$ & $1 \times 2.329(6) ; 1 \times 1.675(6) ; 1 \times 1.868(9) ; 1 \times 1.809(7) ; 1 \times 2.031(8) ; 1 \times 2.066(9)$ \\
$\mathrm{Mo} 3 / \mathrm{Fe} 3$ & $1 \times 1.739(5) ; 1 \times 2.273(5) ; 1 \times 1.838(7) ; 1 \times 2.037(7) ; 1 \times 1.874(9) ; 1 \times 2.023(8)$ \\
\hline
\end{tabular}

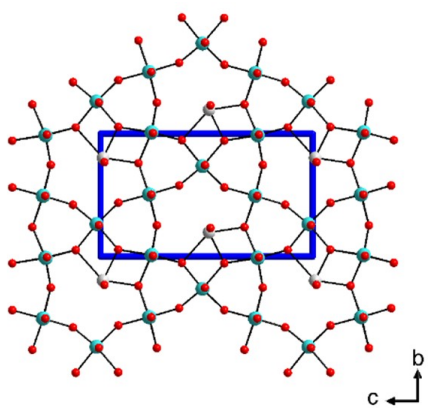

(a)

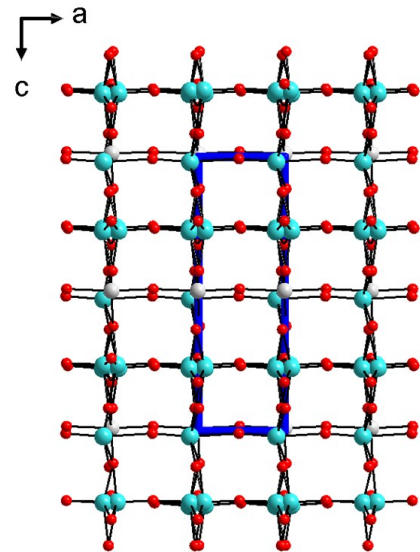

(b)

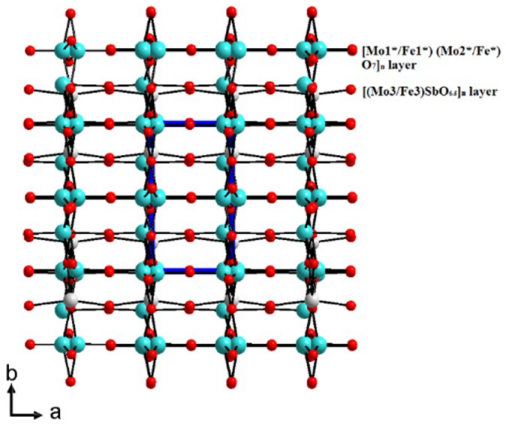

(c)

Figure 3. Overview of the crystal structure of $\mathrm{Fe}_{0.43} \mathrm{Mo}_{2.56} \mathrm{SbO}_{9.5}$ along (a) [100], (b) [010], (c) [001] respectively. $\left(\mathrm{Mo}^{*} / \mathrm{Fe}^{*}\right)=$ light blue, $\mathrm{Sb}=\mathrm{Grey}, \mathrm{O}=\mathrm{Red}$. 


\section{Discussion}

The diffraction data suggests that a hexagonal crystal structure with space group P6/mmm would be a possible solution, but attempts to solve the crystals structure in this space group results in a very poor fit of the data. The solution is however sufficiently good to show the semblance of a hexagonal tungsten bronze type arrangement, the metal indicating a puckering of the layer. This, again, is a common structural response to the presence of a lone-pair element distorting the planar crystal structure and disrupting the mirror plane perpendicular to c.

There is no prescribed order for the modeling of this, but it is natural to first lower the symmetry from hexagonal $\mathrm{P} 6 / \mathrm{mmm}$ to orthorhombic Cmmm and then to consider symmetry lowering compatible with the absence of a mirror plane perpendicular to $c$. This produces seven possible direct subgroups: Pmmn, Pman, Pbmn, Pban, Cmm2, C2/m11, C12/m1. The best result was found for Pbnm, but split positions caused by the symmetry remained and the symmetry was subsequently lowered through $\mathrm{Pb} 2 n$ to $P b 11$. No significant improvement was found on reducing the symmetry to $P 1$. To control the veracity of this result, each of the other six maximal subgroups were taken as starting points for symmetry reduction, but these attempts verified the original result. The crystal structure in the orthorhombic group Pban could be reduced through the path $\mathrm{Pban}-\mathrm{Pb} 2 n-\mathrm{Pb} 11$ to yield the same result as before, as could Cmm2 via Cmm2-Cm11-Pb11 and Cmm2-Pba2-Pb11, but for the other orthorhombic starting points, the symmetry had to be reduced to $P 1$ to yield a solution comparable to that in $P b 11$. The monoclinic group C2/m11 likewise could be reduced via $C 2 / m 11-C m 11-P b 11$ and $C 2 / m 11-P 2 / b 11-P b 11$ to yield the same solution while $C 12 / m 1$ yielded only the $P 1$ solution.

The orientation of $\mathrm{Mo}^{*} / \mathrm{Fe}^{*}$ atoms in the (bc) plane is shown in Figure 4 . The cations $\mathrm{Mo1}^{*} / \mathrm{Fe}^{*}$, $\mathrm{Mo} 2^{*} / \mathrm{Fe} 2 *$, and Mo3/Fe3 forms a pseudo-hexagonal channel, presented by a dotted line, see Figure 4. The distances in between the heavy atoms of the pseudo-hexagon vary from $3.616 \AA$ to $3.837 \AA$ and the angle varies from $114.55^{\circ}$ to $125.69^{\circ}$. The antimony and oxygen atoms reside in the pseudo hexagons made up of six $\mathrm{Mo}^{*} / \mathrm{Fe}^{*}$ and six $\mathrm{O}$ atoms. Inside the pseudohexagon there are two four-membered rings made of $\mathrm{Mo}^{*} / \mathrm{Fe}^{*}, \mathrm{Sb}$ and $\mathrm{O}$ atoms. Disorder manifests itself as a splitting of the metal sites on $\mathrm{Mo}^{*} / \mathrm{Fe}^{*}$ in the pseudohexagons, which is why the symmetry is monoclinic instead of hexagonal. Sb is shifted away from the center of the pseudo 3-fold rotation axis, located in the pseudohexagonal channels.

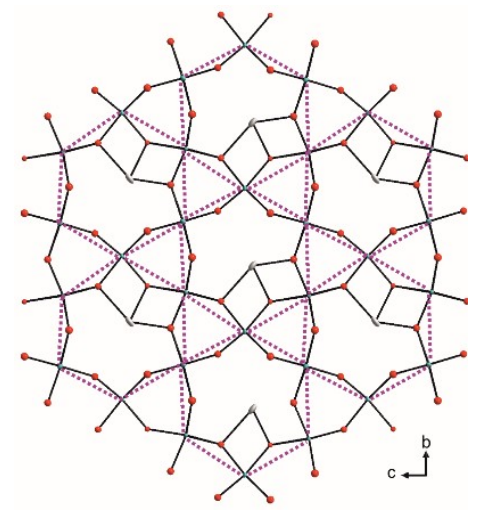

Figure 4. Pseudohexagonal arrangement of the $\mathrm{Mo}^{*} / \mathrm{Fe}^{*}$ atoms in the $(011)$ plane. $\left(\mathrm{Mo}^{*} / \mathrm{Fe}^{*}\right)=\mathrm{Light}$ blue, $\mathrm{Sb}=$ Grey, $\mathrm{O}=$ Red.

\section{Conclusions}

The new compound $\mathrm{Fe}_{0.43} \mathrm{Mo}_{2.56} \mathrm{SbO}_{9.5}$ crystallizes in the monoclinic non-centrosymmetric space group Pc with unit cell parameters $a=4.0003(2) \AA, b=7.3355(3) \AA, c=12.6985(6) \AA, \beta$ $=90^{\circ}$. Five partially occupied sites with $\mathrm{Mo}^{6+} / \mathrm{Fe}^{3+}$ atoms and one $\mathrm{Sb}^{3+}$ atoms are present as crystallographically independent atoms. Several $\left(\mathrm{Mo}^{*} / \mathrm{Fe}^{*}\right)$ sites sit at very short distances due to disorder in the crystal structure as evident from diffuse scattering. The lowering of symmetry confirms distortion in the crystal structure. The $\mathrm{Sb}$ atoms possess distorted octahedra of $\left[\mathrm{SbO}_{4} \mathrm{E}\right]$ units with 
two half occupied oxygen atoms. The $\mathrm{Mo}^{*} / \mathrm{Fe}^{*}$ forms distorted octahedral units of $\left[\left(\mathrm{Mo}^{*} / \mathrm{Fe}^{*}\right) \mathrm{O}_{6}\right]$. Disorder manifests itself as a splitting of the metal sites on $\mathrm{Mo}^{*} / \mathrm{Fe}^{*}$ in the pseudohexagonal channel, which is why lowering the symmetry to monoclinic from hexagonal is found. $\mathrm{Sb}$ is located in the pseudohexagonal channels and is shifted away from the center of the pseudo six-fold rotation axis6.

Supplementary Materials: The following are available online at http://www.mdpi.com/2073-4352/9/1/40/s1, Table S1: Qualitative EDS analyses on single crystals were performed in a scanning electron microscope (JEOL-7000F) showing that all the intended elements are present in $\mathrm{Fe}_{0.43} \mathrm{Mo}_{2.56} \mathrm{SbO}_{9.5}$. Average composition is calculated considering several points in a crystal. Table S2: (a) Structural parameters of the cations and (b) anions in $\mathrm{Fe}_{0.43} \mathrm{Mo}_{2.56} \mathrm{SbO}_{9.5}$ (Occ. = Occupation factor).Details of crystallographic file is deposited to CCDC (CCDC 1889226).

Author Contributions: S.I.A. planned the synthesis, characterization by EDX, data collection by X-ray diffraction, and preparation of the manuscript. S.L. solved the structure and helped in the discussion. M.J. participated in all the discussion with S.I.A. and S.L.

Funding: The work was carried out with financial support from Stiftelsen Olle Engkvist Byggmästare and the Swedish Research Council.

Acknowledgments: S.I.A. thanks Al-Fatehar Education Society for the support and also to S. Dey and S. J. Abbas for their useful discussion.

Conflicts of Interest: The authors declare no conflicts of interest.

\section{References}

1. Hu, S.; Johnsson, M.; Lemmens, P.; Schmid, D.; Menzel, D.; Tapp, J.; Möller, A. Acentric Pseudo-Kagome Structures: The Solid Solution $\left(\mathrm{Co}_{1-\mathrm{x}} \mathrm{Ni}_{\mathrm{x}}\right)_{3} \mathrm{Sb}_{4} \mathrm{O}_{6} \mathrm{~F}_{6}$. Chem. Mater. 2014, 26, 3631-3636. [CrossRef]

2. Yu, H.; Young, J.; Wu, H.; Zhang, W.; Rondinelli, J.M.; Halasyamani, P.S. $\mathrm{M}_{4} \mathrm{Mg}_{4}\left(\mathrm{P}_{2} \mathrm{O}_{7}\right)_{3}(\mathrm{M}=\mathrm{K}, \mathrm{Rb})$ : Structural Engineering of Pyrophosphates for Nonlinear Optical Applications. Chem. Mater. 2017, 29, 1845-1855. [CrossRef]

3. Yu, H.; Zhang, H.; Halasyamani, P.S. Large Birefringent Materials, $\mathrm{Na}_{6} \mathrm{Te}_{4} \mathrm{~W}_{6} \mathrm{O}_{29}$ and $\mathrm{Na}_{2} \mathrm{TeW}_{2} \mathrm{O}_{9}$ : Synthesis, Structure, Crystal Growth, and Characterization. Cryst. Growth Des. 2016, 16, 1081-1087. [CrossRef]

4. Zhang, W.; Halasyamani, P.S. Top-seeded solution crystal growth of noncentrosymmetric and polar $\mathrm{Zn}_{2} \mathrm{TeMoO}_{7}$ (ZTM). J. Solid State Chem. 2016, 236, 32-38. [CrossRef]

5. Rodriguez, E.E.; Cao, H.; Haiges, R.; Melot, B.C. Single crystal magnetic structure and susceptibility of $\mathrm{CoSe}_{2}$ O. J. Solid State Chem. 2016, 236, 39-44. [CrossRef]

6. Nguyen, S.D.; Halesyamani, P.S. Synthesis, Structure, and Characterization of New $\mathrm{Li}^{+}-\mathrm{d}^{0}$ - Lone-PairOxides: Noncentrosymmetric Polar $\mathrm{Li}_{6}\left(\mathrm{Mo}_{2} \mathrm{O}_{5}\right)_{3}\left(\mathrm{SeO}_{3}\right)_{6}$ and Centrosymmetric $\mathrm{Li}_{2}\left(\mathrm{MO}_{3}\right)\left(\mathrm{TeO}_{3}\right)\left(\mathrm{M}=\mathrm{Mo}^{6+}\right.$ or $\mathrm{W}^{6+}$ ). Inorg. Chem. 2012, 51, 9529-9538. [CrossRef] [PubMed]

7. Ali, S.I.; Zhang, W.; Halasyamani, P.S.; Johnsson, M. $\mathrm{Zn}_{3} \mathrm{Sb}_{4} \mathrm{O}_{6} \mathrm{~F}_{6}$ : Hydrothermal synthesis, crystal structure and nonlinear optical properties. J. Solid State Chem. 2017, 256, 158-161. [CrossRef]

8. Becker, R.; Johnsson, M.; Kremer, R.K.; Klauss, H.H.; Lemmens, P. Crystal Structure and Magnetic Properties of $\mathrm{FeTe}_{2} \mathrm{O}_{5} \mathrm{X}(\mathrm{X}=\mathrm{Cl}, \mathrm{Br})$. J. Am. Chem. Soc. 2006, 128, 15469-15475. [CrossRef]

9. Fawcett, J.; Holloway, J.H.; Russell, D.R. Transition-Metal Tetrafluoride Oxide-Antimony Pentafluoride Adducts; Preparation and Characterization of the Adducts $\mathrm{MF}_{4} 0 . \mathrm{SbF}_{5}(\mathrm{M}=\mathrm{Mo}, \mathrm{W}$, or $\mathrm{Re})$ and Crystal Structures of $\mathrm{MoF}_{4} \mathrm{O} \cdot \mathrm{SbF}_{5}$ and $\mathrm{ReF}_{4} \mathrm{O} \cdot \mathrm{SbF}_{5}$. J. Chem. Soc. Dalton Trans. 1980, 5, 1212-1218.

10. Cochrane, A.K.; Telfer, M.; Dixon, C.L.A.; Zhang, W.; Halasyamani, P.S.; Bousquet, E.; Lightfoot, P. $\mathrm{NdBaScO}_{4}$ : Aristotype of a new family of geometric ferroelectrics? Chem. Commun. 2016, 52, 10980-10983. [CrossRef]

11. De Laune, B.P.; Greaves, C. Structural and magnetic characterisation of $\mathrm{CoSb}_{2} \mathrm{O}_{4}$, and the substitution of $\mathrm{Pb}^{2+}$ for $\mathrm{Sb}^{3+}$. J. Solid State Chem. 2012, 187, 225-230. [CrossRef]

12. Zhou, H.D.; Wiebe, C.R.; Janik, J.A.; Vogt, B.; Harter, A.; Dalal, N.S.; Gardner, J.S. Spin glass transitions in the absence of chemical disorder fort hepyrochlores $\mathrm{A}_{2} \mathrm{Sb}_{2} \mathrm{O}_{7}(\mathrm{~A}=\mathrm{Mn}, \mathrm{Co}, \mathrm{Ni})$. Solid State Chem. 2010, 183, 890-894. [CrossRef]

13. Politaev, V.V.; Nalbandyan, V.B.; Petrenko, A.A.; Shukaev, I.L.; Volotchaev, V.A.; Medvedev, B.S. Mixed oxides of sodium, antimony (5+) and divalent metals (Ni, Co, Zn or Mg). J. Solid State Chem. 2010, 183, 684-691. [CrossRef] 
14. Chater, R.; Gavarri, J.R. Structures isomorphes $\mathrm{MeX}_{2} \mathrm{O}_{4}$ - Evolution structurale entre $2 \mathrm{~K}$ et $300 \mathrm{~K}$ de I'antimonite $\mathrm{FeSb}_{2} \mathrm{O}_{4}$ : Elasticit et ordremagnktique Anisotropies. J. Solid State Chem. 1985, 60, 78-86. [CrossRef]

15. Shanmugavani, A.; Lalitha, M.; Yuvaraj, S.; Vasylechko, L.; Meyrick, D.; Senthilkumar, L.; Selvan, R.K. Facile Hydrothermal Synthesis and First Principle Computational Studies of $\mathrm{NiSb}_{2} \mathrm{O}_{4}$ and Its Electrochemical Properties with $\mathrm{Ni}_{3}\left(\mathrm{Fe}(\mathrm{CN})_{6}\right)_{2}\left(\mathrm{H}_{2} \mathrm{O}\right)$ for Hybrid Supercapacitors. ChemistrySelect 2017, 2, 6823. [CrossRef]

16. Gavarri, J.R.; Hewat, A.W. Les antimonites antiferromagnetiques $\mathrm{MnSb}_{2} \mathrm{O}_{4}$ et $\mathrm{NiSb}_{2} \mathrm{O}_{4}$. J. Solid State Chem. 1983, 49, 14-19. [CrossRef]

17. Donaldson, D.J.; Kjekshus, A.; Nicholsonm, D.G.; Rakke, T. Properties of Sb-compounds with Rutile-like structures. Acta Chem. Scand. 1975, 29, 803-809. [CrossRef]

18. Reimers, J.N.; Greedan, J.E.; Stager, C.V.; Kremer, R. Crystal Structure and Magnetism in $\mathrm{CoSb}_{2} \mathrm{O}_{6}$ and $\mathrm{CoTa}_{2} \mathrm{O}_{6}$. J. Solid State Chem. 1989, 83, 20-30. [CrossRef]

19. Antic, B.; Rodic, D.; Tellgren, R.; Rundlof, H. Neutron diffraction study of the magnetic and structure properties of $\mathrm{Co}_{2.50} \mathrm{Sb}_{0.50} \mathrm{O}_{4}$ spinel. J. Magn. Magn. Mater. 2000, 219, 41-44. [CrossRef]

20. Ali, S.I.; Kremer, R.K.; Johnsson, M. Hydrothermal Synthesis and Magnetic Characterization of the Quaternary Oxide $\mathrm{CoMo}_{2} \mathrm{Sb}_{2} \mathrm{O}_{10}$. Inorg. Chem. 2016, 55, 11490-11496. [CrossRef]

21. Primo-Martin, V.; Jansen, M. Synthesis, Structure, and Physical Properties of Cobalt Perovskites: $\mathrm{Sr}_{3} \mathrm{CoSb}_{2} \mathrm{O}_{9}$ and $\mathrm{Sr}_{2} \mathrm{CoSbO}_{6-\delta}$. J. Solid State Chem. 2001, 157, 76-85. [CrossRef]

22. Istomin, S.Y.; Koutcenko, V.A.; Antipov, E.V.; Lindberg, F.; Svensson, G. Synthesis and characterization of novel 6- $\mathrm{H}$ perovskites $\mathrm{Ba}_{2} \mathrm{Co}_{2-\mathrm{x}} \mathrm{Sb}_{\mathrm{x}} \mathrm{O}_{6-\mathrm{y}}, 0.6 \leq \mathrm{x} \leq 0.8$ and $\mathrm{x}=1.33\left(\mathrm{Ba}_{3} \mathrm{CoSb}_{2} \mathrm{O}_{9}\right)$. Mater. Res. Bull. 2004, 39, 1013-1022. [CrossRef]

23. Whitaker, M.J.; Bayliss, R.D.; Berry, F.J.; Greaves, C. The synthesis, structure, magnetic and electrical properties of $\mathrm{FeSb}_{2-\mathrm{x}} \mathrm{Pb}_{\mathrm{x}} \mathrm{O}_{4}$. J. Mater. Chem. 2011, 21, 14523. [CrossRef]

24. Brookes, C.; Bowker, M.; Wells, P.P. Catalysts for the Selective Oxidation of Methanol. Catalysts 2016, 6, 92. [CrossRef]

25. Brookes, C.; Wells, P.P.; Dimitratos, N.; Jones, W.; Gibson, E.K.; Morgan, D.J.; Cibin, G.; Nicklin, C.; Mora-Fonz, D.; Scanlon, D.O.; et al. The Nature of the Molybdenum Surface in Iron Molybdate. The Active Phase in Selective Methanol Oxidation. J. Phys. Chem. C 2014, 118, 26155-26161. [CrossRef]

26. Oxford Diffraction. CrysAlis CCD and CrysAlis RED; Oxford Diffraction Ltd.: Abingdon, Oxfordshire, UK, 2008.

27. Sheldrick, G.M. SADABS, Version 2008/1; Bruker AXS Inc.: Billerica, MA, USA, 2008.

28. Palatinus, L.; Chapuis, G. SUPERFLIP-A computer program for the solution of crystal structures by charge flipping in arbitrary dimensions. J. Appl. Crystallogr. 2007, 40, 785-790. [CrossRef]

29. Petricek, V.; Dusek, M.; Palatinus, L. Crystallographic Computing System JANA2006: General features. Z. Kristallogr. Cryst. Mater. 2014, 229, 345-352. [CrossRef]

30. Svensson, C. Refinement of the Crystal Structure of Cubic Antimony Trioxide, $\mathrm{Sb}_{2} \mathrm{O}_{3}$. Acta Crystallogr. Sect. B Struct. Crystallogr. Cryst. Chem. 1975, 31, 2016-2018. [CrossRef]

31. Ali, S.I.; Johnsson, M. Antimony oxofluorides-A synthesis concept that yields phase pure samples and single crystals. Dalton Trans. 2016, 45, 12167-12173. [CrossRef] [PubMed]

32. Brown, I.D. Chemical Bond in Inorganic Chemistry; Oxford University Press: NewYork, NY, USA, 2002.

(C) 2019 by the authors. Licensee MDPI, Basel, Switzerland. This article is an open access article distributed under the terms and conditions of the Creative Commons Attribution (CC BY) license (http://creativecommons.org/licenses/by/4.0/). 